\title{
Biochar Impacts Soil Microbial Community Composition and Nitrogen Cycling in an Acidic Soil Planted with Rape
}

\author{
Hui-Juan $\mathrm{Xu}^{\dagger, \S, \|}$ Xiao-Hui Wang, ${ }^{\ddagger, \S, \|} \mathrm{Hu} \mathrm{Li}^{\dagger,}{ }^{\dagger}$, Huai-Ying Yao, ${ }^{\dagger}$ Jian-Qiang Su, ${ }^{\dagger}$ and Yong-Guan Zhu, ${ }^{* \dagger, \ddagger}$ \\ ${ }^{\dagger}$ Key Laboratory of Urban Environment and Health, Institute of Urban Environment, Chinese Academy of Sciences, Xiamen 361021, \\ People's Republic of China \\ ${ }^{\ddagger}$ State Key Lab of Urban and Regional Ecology, Research Center for Eco-environmental Sciences, Chinese Academy of Sciences, \\ Beijing 100085, People's Republic of China \\ ${ }^{\S}$ University of Chinese Academy of Sciences, Beijing 100049, People's Republic of China
}

Supporting Information

ABSTRACT: Biochar has been suggested to improve acidic soils and to mitigate greenhouse gas emissions. However, little has been done on the role of biochar in ameliorating acidified soils induced by overuse of nitrogen fertilizers. In this study, we designed a pot trial with an acidic soil ( $\mathrm{pH} 4.48)$ in a greenhouse to study the interconnections between microbial community, soil chemical property changes, and $\mathrm{N}_{2} \mathrm{O}$ emissions after biochar application. The results showed that biochar increased plant growth, soil $\mathrm{pH}$, total carbon, total nitrogen, $\mathrm{C} / \mathrm{N}$ ratio, and soil cation exchange capacity. The results of high-throughput sequencing showed that biochar application increased $\alpha$-diversity significantly and changed the relative abundances of some microbes that are related with

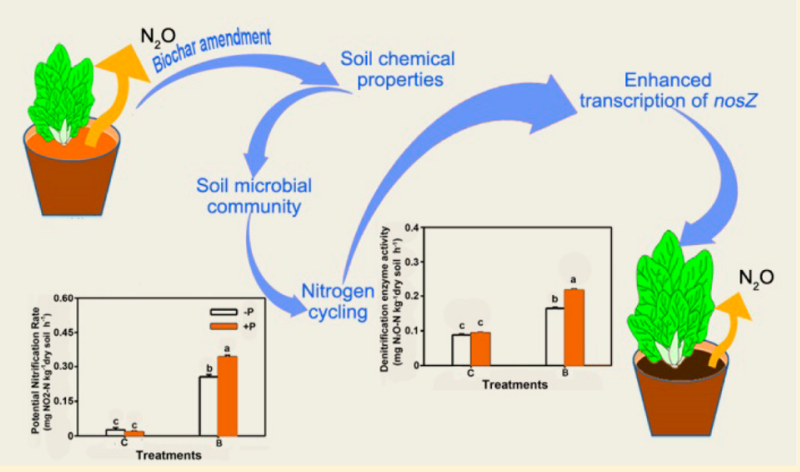
carbon and nitrogen cycling at the family level. Biochar amendment stimulated both nitrification and denitrification processes, while reducing $\mathrm{N}_{2} \mathrm{O}$ emissions overall. Results of redundancy analysis indicated biochar could shift the soil microbial community by changing soil chemical properties, which modulate $\mathrm{N}$-cycling processes and soil $\mathrm{N}_{2} \mathrm{O}$ emissions. The significantly increased nos $\mathrm{Z}$ transcription suggests that biochar decreased soil $\mathrm{N}_{2} \mathrm{O}$ emissions by enhancing its further reduction to $\mathrm{N}_{2}$.

\section{INTRODUCTION}

Long-term overuse of nitrogen fertilizers and acid deposition have been shown to accelerate the soil acidifying processes in China, ${ }^{1,2}$ and increase $\mathrm{N}_{2} \mathrm{O}$ emissions. ${ }^{3}$ Acidification can affect both the soil biota and biogeochemical processes, ${ }^{4}$ thus decreasing agricultural production. Furthermore, a lower soil $\mathrm{pH}$ leads to a higher $\mathrm{N}_{2} \mathrm{O}: \mathrm{N}_{2}$ ratio of soil emitted gases ${ }^{5,6}$ thus posing environmental risks, such as climate change. Although several technologies (e.g., liming and amendments from plant materials) have been developed to remediate acidified soils, they all have drawbacks (e.g., unavailable in many areas, high costs, short lasting of ameliorating effects). ${ }^{7}$ A cost-effective soil amendment is required to solve this issue, and biochar amendment has been proposed as one of such solutions.

Biochar has been reported to modify soil quality characteristics, thereby increasing crop yields. ${ }^{8}$ Because it is usually alkaline, biochar can increase the $\mathrm{pH}$ of acidic soils. ${ }^{9,10}$ Furthermore, biochar application has also been promoted as a means of contributing to the mitigation of climate change by reducing soil $\mathrm{N}_{2} \mathrm{O}$ emissions. ${ }^{11,12}$ However, not all studies have shown that biochar could suppress soil $\mathrm{N}_{2} \mathrm{O}$ emissions. Some has shown no effect ${ }^{13}$ and some that biochar increased soil $\mathrm{N}_{2} \mathrm{O}$ emissions. $^{14}$
In addition to the uncertain effect of biochar on $\mathrm{N}_{2} \mathrm{O}$ emission, the factors and mechanisms of the influence of biochar on $\mathrm{N}_{2} \mathrm{O}$ remain unclear due to the complex $\mathrm{N}_{2} \mathrm{O}$ formation pathways. $\mathrm{N}_{2} \mathrm{O}$ can be produced from several closely related biological processes in soil, including nitrification, nitrifier denitrification, denitrification, codenitrification, dissimilatory nitrate reduction to ammonia, nitrate assimilation, and chemodenitrification, among which nitrification and denitrification are predominant. ${ }^{15}$ Since $\mathrm{N}_{2} \mathrm{O}$ can be the final or intermediate product of denitrification (including nitrifier denitrification), there are two possible ways to decrease denitrification $\mathrm{N}_{2} \mathrm{O}$ emissions: (i) a decrease in the total $\mathrm{N}$ denitrified; and (ii) an increase in the further reduction of $\mathrm{N}_{2} \mathrm{O}$ to $\mathrm{N}_{2}$. Although the ways to decrease nitrification $\mathrm{N}_{2} \mathrm{O}$ have not been well characterized, it has been shown that the decreases of soil $\mathrm{N}_{2} \mathrm{O}$ emissions were often accompanied by lower nitrification rates. ${ }^{16}$ Several hypotheses have been proposed for $\mathrm{N}_{2} \mathrm{O}$ decreases by biochar, including: (i) biochar reduces levels of denitrification via improving soil aeration; ${ }^{17}$ (ii)

Received: April 30, 2014

Revised: July 8, 2014

Accepted: July 23, 2014

Published: July 23, 2014 
biochar increases the adsorption of $\mathrm{NO}_{3}{ }^{-}$, thus decreasing substrate availability for denitrification; ${ }^{18}$ (iii) biochar increases soil $\mathrm{pH}$ therefore driving denitrification thorough to $\mathrm{N}_{2}{ }^{18}$ (iv) biochar sorbs $\mathrm{N}_{2} \mathrm{O}^{19}$ and (v) biochar contains ethylene which could inhibit nitrification and thus the formation of $\mathrm{NO}_{3}{ }^{-}$and $\mathrm{N}_{2} \mathrm{O}^{20}$ More studies are needed to clarify the effect of biochar, especially when it is used as a soil amendment in agricultural production.

Nitrification and denitrification are both performed by soil microbial communities, however, few of the hypotheses stated above have been well supported by microbial studies conducted by advanced methods. Although the majority of biochar- $\mathrm{C}$ is thought to be largely unavailable to microbes, ${ }^{21}$ some studies based on traditional microbial methods have shown that biochar addition to soil could increase soil microbial biomass and soil respiration. ${ }^{22,23}$ However, only a few studies have investigated the changes of soil microbial community composition $^{24}$ and $\mathrm{N}_{2} \mathrm{O}$-related functional gene abundances and transcripts ${ }^{25-27}$ after biochar application. More work is needed to find out the potential effect of biochar on soil microbial community composition and soil microbes, especially those underpinning $\mathrm{N}_{2} \mathrm{O}$-related $\mathrm{N}$-transformation processes, by using advanced methods. Recently, barcoded Illumina paired-end sequencing (amplicon sequencing) method has provided a low cost-effective way to study the soil microbial community. ${ }^{28}$

To study the effects of biochar application on the soil microbial community and to explore the microbial mechanisms of biochar-induced changes in $\mathrm{N}_{2} \mathrm{O}$ emissions in agricultural production, we designed a pot trial in a greenhouse using rape, which is a widely planted vegetable in China with an appropriate growth season for the study. We applied Illumina sequencing technology to analyze shifts in the soil microbial community and chose nirK and nirS, as well as nos $Z$ as denitrifying bacteria gene markers, ${ }^{29,30}$ and gene amo $A$ (including archaeal $a m o A$ and bacterial $a m o A$ ) as nitrification functional markers. ${ }^{31}$ The objectives of this study were as follows: (i) to study the effects of biochar on soil properties and $\mathrm{N}_{2} \mathrm{O}$ emissions from soil with and without rape; (ii) to study the shift in microbial community composition after biochar addition; (iii) to reveal the responses of nitrifier and denitrifier populations to biochar addition; and (iv) to determine the mechanisms of increasing or reducing $\mathrm{N}_{2} \mathrm{O}$ emissions by biochar amendment.

\section{EXPERIMENTAL SECTION}

Soil Characteristics. The soil (belonging to Acrisol according to the World Reference Base for Soil Resources) was collected from the plough layer $(0-20 \mathrm{~cm}$ in depth) of a greenhouse (16 years old) in a vegetable production center $\left(31^{\circ} 50^{\prime} \mathrm{N}, 118^{\circ} 28^{\prime} \mathrm{E}\right)$ located in He County, Anhui Province, China. This area belongs to a subtropical humid monsoon climate region, with a mean annual rainfall of $1067 \mathrm{~mm}$, a mean annual temperature of $15.8{ }^{\circ} \mathrm{C}$, featuring four distinct seasons. Muskmelon was planted in spring and rape was planted in autumn in the greenhouse with potassium sulfate as base fertilizer and fertigation during the growth season. Upon arrival at the lab, the soil was passed through a $2 \mathrm{~mm}$ sieve and airdried before mixed with biochar. The water content of the airdried soil was $4.39 \% \pm 0.05 \%$ (standard deviation). The basic chemical properties and element composition of the soil are shown in Supporting Information (SI) Tables S1 and S2.
Biochar Preparation and Characteristics. Biochar used in this experiment was made from rice straw, sourced from Xiamen, Fujian, China. Air-dried rice stalks were charred at 500 ${ }^{\circ} \mathrm{C}$ for $4 \mathrm{~h}$ in a closed container under oxygen-limited conditions using nitrogen as the medium gas in a muffle furnace (Isotemp, Fisher Scientific, U.S.A.). Biochar was milled to pass a $2 \mathrm{~mm}$ sieve before analysis and application to the soils. The basic properties and element composition of the biochar are shown in SI Tables S1 and S2.

Rape Preparation and Pot Trial. The type of the rape was Jingguan (Brassica campestris L., cv. Jingguan), a hybrid cultivated by the National Engineering Research Center for vegetables. The rape could grow easily, and was strongly resistant to disease and heat, with a growing period of 40-45 d.

In this pot trial, four treatments with four replicates were carried out: addition of $5 \%(\mathrm{w} / \mathrm{w})$ rice straw biochar with rape (BP), addition of $5 \%(\mathrm{w} / \mathrm{w})$ rice straw biochar without rape (B), untreated soil with rape $(\mathrm{CP})$, and untreated soil without rape $(\mathrm{C})$. The main procedures are described as follows. We mixed $21.9 \mathrm{~kg}$ air-dried soil (equals to $20.9 \mathrm{~kg}$ oven dry basis) and $1.1 \mathrm{~kg}$ biochar, weighed $2 \mathrm{~kg}$ soil or mixture of soil and biochar into each pot, and activated the soil microbes by incubating the soil for a week at a water content of about $50 \%$ WHC (water holding capacity). After a week, uniform rape seedlings (the preparation of the seedlings is shown in the SI) were transplanted into the pots $(17.5 \mathrm{~cm}$ diameter, $20 \mathrm{~cm}$ height). After being transplanted into the pots, the rape plants were grown in a greenhouse at a temperature of $28-36{ }^{\circ} \mathrm{C}$ and a relative humidity of $90 \%$. The water content was maintained at about $50 \%$ WHC and no fertilizer was added during the incubation.

Nitrous oxide $\left(\mathrm{N}_{2} \mathrm{O}\right)$ fluxes were measured by using the closed chamber method (see SI) every week for 6 weeks. Gas samples ( $60 \mathrm{~mL}$ each time) were taken 0 and $2 \mathrm{~h}$ after chamber closure. The $\mathrm{N}_{2} \mathrm{O}$ concentrations were analyzed with the robotized incubation system. ${ }^{32}$ Six weeks later, a soil sample from each pot was blended carefully, divided into parts and stored differently as required. One subsample was immediately frozen in liquid $\mathrm{N}_{2}$ and stored at $-80{ }^{\circ} \mathrm{C}$ until used for DNA and RNA extraction. The remainder was sieved with a $2 \mathrm{~mm}$ sieve, after which some was stored at $4{ }^{\circ} \mathrm{C}$ for determination of moisture, nitrate, ammonium, potential nitrification rate (PNR), and denitrification enzyme activity (DEA) within 3 days, and some was air-dried for analysis of soil $\mathrm{pH}$, cation exchange capacity (CEC), total carbon (TC), and total nitrogen (TN).

Soil and Plant Chemical Analysis. Soil $\mathrm{pH}$ was determined with a soil to water ratio of $1: 2.5(\mathrm{w} / \mathrm{v})$ using a pH-meter (accumet excel XL 60, Fisher Scientific, Singapore). CEC was determined by the $\mathrm{BaCl}_{2}$ replacement method. Soil nitrate and ammonium were extracted with $2 \mathrm{M} \mathrm{KCl}$ at a soil to solution ratio of $1: 10(\mathrm{w} / \mathrm{v})$ and determined by a Continuous Flow Analyzer (SAN++, Skalar, Breda, Holland). PNR was measured using a chlorate inhibition method. ${ }^{33}$ DEA was determined by using the acetylene $\left(\mathrm{C}_{2} \mathrm{H}_{2}\right)$ inhibition technique. ${ }^{34}$ Total nitrogen and total carbon were determined by an Element Analyzer (Vario EL III, Elementar, Hanau, Germany). Moisture content was calculated by the weight of soils before and after being oven-dried for $48 \mathrm{~h}$ at $105^{\circ} \mathrm{C}$.

Rape biomass was weighed after washing with deionized water and dried $48 \mathrm{~h}$ at $80{ }^{\circ} \mathrm{C}$. Inorganic nitrogen was determined using fresh rape. Rape nitrate and ammonium contents were determined by grinding extraction method (see 
Table 1. Chemical Properties of Soils under Different Treatments ${ }^{a}$

$\begin{array}{cccccccc}\text { treatments } & \mathrm{pH} & \mathrm{TN}\left(\mathrm{g} \mathrm{kg}^{-1}\right) & \mathrm{TC}\left(\mathrm{g} \mathrm{kg}^{-1}\right) & \mathrm{C} / \mathrm{N} & \mathrm{NO}_{3}^{-}\left(\mathrm{mg} \mathrm{kg}^{-1}\right) & \mathrm{NH}_{4}^{+}\left(\mathrm{mg} \mathrm{kg}^{-1}\right) & \left.\mathrm{CEC}_{(\mathrm{cmol} \mathrm{kg}}^{-1}\right) \\ \mathrm{C} & 4.48 \pm 0.02 \mathrm{~d} & 2.3 \pm 0.1 \mathrm{c} & 14.1 \pm 0.2 \mathrm{~b} & 6.09 \pm 0.03 \mathrm{~d} & 166.8 \pm 2.3 \mathrm{a} & 5.47 \pm 0.41 \mathrm{a} & 0.021 \pm 0 \mathrm{c} \\ \mathrm{CP} & 4.56 \pm 0.02 \mathrm{c} & 2.2 \pm 0.1 \mathrm{~d} & 14.7 \pm 0.3 \mathrm{~b} & 6.65 \pm 0.12 \mathrm{c} & 51.76 \pm 1.09 \mathrm{c} & 5.48 \pm 0.36 \mathrm{a} & 0.023 \pm 0 \mathrm{~b} \\ \mathrm{~B} & 6.03 \pm 0.02 \mathrm{~b} & 3.1 \pm 0.1 \mathrm{a} & 41.3 \pm 1.0 \mathrm{a} & 13.53 \pm 0.27 \mathrm{~b} & 152.0 \pm 1.2 \mathrm{~b} & 4.32 \pm 0.03 \mathrm{~b} & 0.027 \pm 0 \mathrm{a} \\ \mathrm{BP} & 6.17 \pm 0.01 \mathrm{a} & 2.8 \pm 0.1 \mathrm{~b} & 39.9 \pm 0.6 \mathrm{a} & 14.17 \pm 0.13 \mathrm{a} & 51.96 \pm 3.01 \mathrm{c} & 5.29 \pm 0.30 \mathrm{a}\end{array}$

${ }^{a}$ Different letters in a single column indicate significant difference between the treatments at $p<0.05$. C: biochar untreated soil without rape, CP: biochar untreated soil with rape, B: biochar treated soil without rape, and BP: biochar treated soil with rape.

SI). Rape nitrite was determined by spectrometric method according to National food safety standards (see SI).

DNA Extraction and Illumina Sequencing. DNA was extracted from $0.5 \mathrm{~g}$ soil using the FastDNA SPIN kit for Soil (MP Biomedicals, Solon, OH, USA) according to the manufacturer's instruction. The DNA was dissolved in $50 \mu \mathrm{L}$ of sterilized deionized and free of nucleases water and stored at $-20{ }^{\circ} \mathrm{C}$ before use for Illumina sequencing.

The V3 region of the $16 \mathrm{~S}$ rRNA gene was used as the bacterial-specific fragment using the primers $338 \mathrm{~F}$ ( $5^{\prime}$-ACT CCT ACG GGA GGC AGC AG-3') and 533R (5'-TTA CCG CGG CTG CTG GCA C-3'). ${ }^{35}$ Each pair of primers used to amplify a certain soil sample were barcoded with a unique error-correcting eight-base barcode ${ }^{36}$ on both forward and reverse primers. All amplifications were performed in 4-fold 25 $\mu \mathrm{L}$ reactions, while each reaction volume contained $1 \mu \mathrm{L}$ of DNA template (about $20 \mathrm{ng}$ ), $0.5 \mu \mathrm{L}$ of each appropriate primer (at a final concentration of $0.2 \mu \mathrm{M}$ ), $0.25 \mu \mathrm{L}$ of bovine serum albumin (BSA, at a final concentration of $6 \mathrm{mM}$ ) (Takara, Japan), $12.5 \mu \mathrm{L}$ of $2 \times$ DreamTaq Green PCR Master Mix (Thermo Scientific, U.S.A.). The PCR conditions, performed in a LifePro Thermal Cycler (Hangzhou Bioer Technology Co. Ltd., Hangzhou, China), consisted of an initial denaturation step at $95^{\circ} \mathrm{C}$ for $3 \mathrm{~min}$, followed by 35 cycles at $95{ }^{\circ} \mathrm{C}$ for $30 \mathrm{~s}, 55{ }^{\circ} \mathrm{C}$ for $30 \mathrm{~s}$ and $72{ }^{\circ} \mathrm{C}$ for $30 \mathrm{~s}$, and a final extension step at $72{ }^{\circ} \mathrm{C}$ for $5 \mathrm{~min}$. 4-fold reactions of each sample were pooled and purified by agarose gel electrophoresis with a MinElute PCR Purification Kit (Qiagen, Germany). The concentrations of purified products were quantified using SpectraMax M5 (Molecular Devices) with PicoGreen. ${ }^{37}$ The pooled samples were sent to BGI and sequenced on an Illumina Hiseq2000 platform (Illumina, San Diego, CA, U.S.A.).

RNA Extraction and Real-Time PCR. RNA was extracted based on the bead-beating method previously described by Griffiths et al. ${ }^{38}$ with slight modification (see SI). Total RNA was purified using the AllPrep DNA/RNA Mini Kit (Qiagen, Germany) and digested with DNase I (Thermo Scientific, Canada). Reverse transcription of $16 \mathrm{~S} r R N A$ was performed with random hexamer primers $(0.5 \mu \mathrm{g})$ using the Reverse Transcription System (Promega Corporation, Madison, U.S.A.) according to the manufacturer's instruction, while those of all the functional genes used gene-specific primers in the RT-PCR (see SI Table S3).

Quantification of archaeal and bacterial $16 \mathrm{~S} r R N A$, and archaeal and bacterial amoA, nirK, nirS, and nos $Z$ transcripts were performed on a 7500 real-time PCR system (Applied Biosystems, Germany). For the bacterial 16S $r R N A$, the $20 \mu \mathrm{L}$ PCR mixture contained $10 \mu \mathrm{L}$ of Premix Ex Taq (TaKaRa, Japan), $0.2 \mu \mathrm{M}$ of each primer, $0.2 \mathrm{mg} \mathrm{mL}^{-1} \mathrm{BSA}, 0.4 \mu \mathrm{M}$ Taqman Probe, $0.4 \mu \mathrm{L}$ ROX Reference Dye and 1-10 ng cDNA. For the other genes, the $20-\mu \mathrm{L}$ reaction mixtures contained $10 \mu \mathrm{L}$ of SYBR Premix Ex TaqII (TaKaRa, Japan), $0.2 \mu \mathrm{M}$ of each primer, $0.25 \mu \mathrm{L}$ of $0.2 \mathrm{mg} \mathrm{mL}^{-1} \mathrm{BSA}, 0.4 \mu \mathrm{L}$
ROX Reference Dye and 1-10 ng cDNA. Thermal cycling conditions and primers used for each reaction are described in SI Table S3. Plasmid pGEM-T Easy Vector (3015 bp, Promega, Madison, U.S.A.) was used in the cloning of gene fragments to establish standard curves for quantitative PCR (see SI).

High-Throughput Sequencing Data Preprocessing. Data yielded from Illumina sequencing were analyzed using the Quantitative Insights Into Microbial Ecology (QIIME 1.6.0) toolkit. ${ }^{39}$ The process of analyses is described as follows: (i) removed any low quality or ambiguous reads; (ii) assigned taxonomy of the qualified sequence reads using RDP classifier at a $97 \%$ identity threshold; (iii) removed putative chimeras and singletons from OTU tables generated from highthroughput sequencing data; (iv) calculated $\alpha$ - diversity indices (Shannon-Weaver index $(\mathrm{H}), \mathrm{PD}$ whole tree, observed species and chao1) to assess the internal (within-sample) complexity of individual microbial populations; and (v) computed $\beta$-diversity using the unweighted UniFrac metric. ${ }^{40}$

Statistical Analysis. Univariate statistical and correlation analyzes were performed using SPSS 18.0 (SPSS Inc., Chicago, III, U.S.A.) and Sigmaplot 12.0 (Systat Software, Inc., San Jose, CA). The statistical significance of the differences between samples was determined by Duncan's multiple range test. $P$ values $<0.05$ were considered significant. RDA were performed using R (2.14.0, http://www.r-project.org/) with the community ecology package "vegan $(2.0-10)$ ". ${ }^{4}$ Envfit function (999 permutations) was used to choose significant environmental factors. Adonis was used to test the microbial community composition significance between treatments.

\section{RESULTS}

Soil Chemical Properties. Changes in the chemical properties of soil in the four treatments are displayed in Table 1 . The addition of biochar significantly increased soil $\mathrm{pH}$ from $4.48 \pm 0.01$ to $6.03 \pm 0.01$ without rape, and from $4.56 \pm$ 0.02 to $6.17 \pm 0.02$ with rape. TC, TN, C/N ratio, and CEC were also significantly increased with biochar application. There was no difference in final $\mathrm{NO}_{3}{ }^{-}$concentration between $\mathrm{CP}$ and $\mathrm{BP}$, which were much lower than those in soils without rape. Final $\mathrm{NO}_{3}{ }^{-}$and $\mathrm{NH}_{4}{ }^{+}$concentrations in $\mathrm{B}$ were lower in those with in $\mathrm{C}$. Planting rape also increased soil $\mathrm{pH}$, but the effect was not as strong as those treated with biochar. Planting rape had no effect on TC, however decreased $\mathrm{TN}$, resulting in the increase of the $\mathrm{C} / \mathrm{N}$ ratio.

Biochar addition increased rape shoot biomass from $2.31 \pm$ 0.19 to $4.23 \pm 0.21 \mathrm{~g}$ dry weight per pot (standard error). Biochar also decreased total $\mathrm{N}$ and inhibited $\mathrm{NO}_{2}{ }^{-}$ accumulation in rape shoot, but had no effects on shoot total $\mathrm{C}$, ammonium, and nitrate.

$\mathrm{N}_{2} \mathrm{O}$ Emissions, Nitrification and Denitrification Activities. Biochar addition reduced $\mathrm{N}_{2} \mathrm{O}$ emissions regardless of plantation (Figure 1). For the treatments without plant, biochar decreased $\mathrm{N}_{2} \mathrm{O}$ emissions from the second week, while 


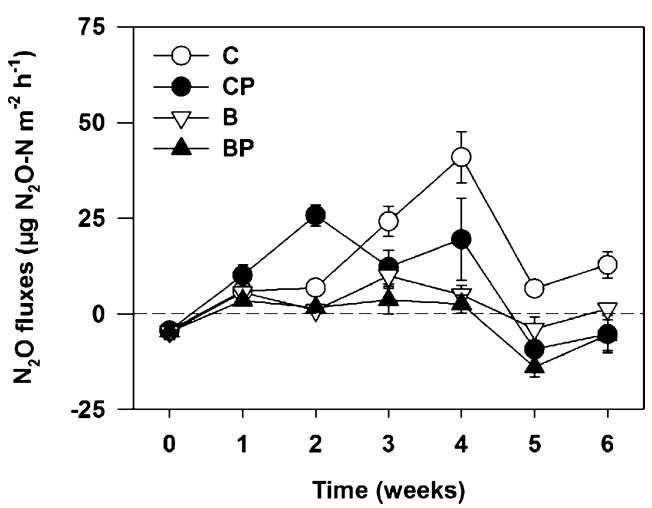

Figure 1. $\mathrm{N}_{2} \mathrm{O}$ emissions in greenhouse soil every week during the rape growth period ( $n=4$; error bars represent standard errors). C: biochar untreated soil without rape, CP: biochar untreated soil with rape, $\mathrm{B}$ : biochar treated soil without rape, and BP: biochar treated soil with rape.

for the treatments with plant, biochar addition only significantly decreased $\mathrm{N}_{2} \mathrm{O}$ emission in the second and fourth week. Rape planting also had some effect on $\mathrm{N}_{2} \mathrm{O}$ emission. For the untreated soils, rape planting increased $\mathrm{N}_{2} \mathrm{O}$ emissions during the first 2 weeks and decreased from the third week.

We summed the total $\mathrm{N}_{2} \mathrm{O}$ emission during the sampling period (over $2 \mathrm{~h}$ ) determined each week (SI Figure S1). According to SI Figure S1, treatment $\mathrm{C}$ emitted the highest cumulative $\mathrm{N}_{2} \mathrm{O}$, followed by $\mathrm{CP}$ and $\mathrm{B}$. The total $\mathrm{N}_{2} \mathrm{O}$ accumulation in $\mathrm{BP}$ is negative, which shows that the soil with the biochar amendment and rape planting could be more likely a sink for $\mathrm{N}_{2} \mathrm{O}$. Generally, biochar decreased $\mathrm{N}_{2} \mathrm{O}$ accumulation significantly irrespective of planting.

Potential nitrification rates and denitrification enzyme activity of soils treated with biochar, are much higher than those without biochar (Figure 2). Nitrification and denitrification showed similar responses to biochar addition and rape planting. BP had the highest nitrification and denitrification activities, followed by the treatment $B$.

Shift of Microbial Community Composition under Biochar Application. After demultiplexing and quality filtering, 723854 high-quality sequences were obtained in total (more information see SI). To compare the microbial community diversity among all the soils, a sequencing depth of 19772 sequences were randomly selected from each sample in the sequencing library. Rarefaction of observed species showed that even at a sequencing depth of 19772 , the diversity of soil bacteria continued to rapidly increase with increasing sequencing depth (SI Figure S2), which illustrated the high diversity of soil bacteria. All diversity indices showed that bacterial community diversities in treatments with biochar amendment were higher than those in control soils (SI Table S4).

The most abundant phyla were Proteobacteria, Acidobacteria, Chloroflexi, Actinobacteria, Firmicutes, TM7, Gemmatimonadetes and Bacteroidetes, and these taxa accounted for more than $91 \%$ of the bacterial sequences in all soils of the four treatments (SI Figure S3). As shown in SI Figure S4, Acidobacteria was the most sensitive phylum to biochar, with relative abundances decreasing from $17.8 \%$ to $6.1 \%, 17.2 \%$ to $5.9 \%$ with and without rape, respectively. Chloroflexi was also significantly decreased by biochar, from $15.2 \%$ to $10.7 \%$ with rape planting, and from $14.7 \%$ to $10.3 \%$ without rape planting. On the other hand, Bacteroidetes, Gemmatimonadetes, and TM7 were noticeably increased after biochar application. Treatment B had the highest Firmicutes abundance (19.1\%), while the abundances in C, CP, and BP were $12.5 \%, 13.3 \%$, and $13.5 \%$, respectively. Proteobacteria, Actinobacteria, and Cyanobacteria showed no response to biochar treatment or rape planting. Rape planting was observed to only have an effect on Firmicutes and Gemmatimonadetes with biochar amendment, and had no obvious effects on the other phyla relative abundances.

Families, those have a relative abundance higher than $1.5 \%$ in at least two treatments, were selected for analysis. As shown in Table 2, at the family level the relative abundances of Acidobacteriaceae, Koribacteraceae, Solibacteraceae, Bradyrhizobiaceae, Gaiellaceae, and Rhodospirillaceae were significantly lower in biochar treatments than those in the controls, while the relative abundances of Sphingomonadaceae, Flammeovirgaceae, Hyphomicrobiaceae, and Chitinophagaceae were significantly higher after biochar application. Without rape, biochar amendment significantly decreased the relative of Xanthomonadaceae, and increased the relative abundance of Bacillaceae. Although the relative abundances of Clostridiaceae were higher than $2 \%$, there was no significant difference between treatments.

The RDA plots of the bacterial communities at the family level clearly indicated that the bacterial community composition of the samples was strongly changed by biochar application (Figure 3). Upon ADONIS analysis, the soil bacterial community composition was significantly changed by biochar. However, rape only had significant effect on the soil bacterial community composition with biochar amendment (BP and B), but not without biochar ( $\mathrm{CP}$ and $\mathrm{C})$. The first axis could
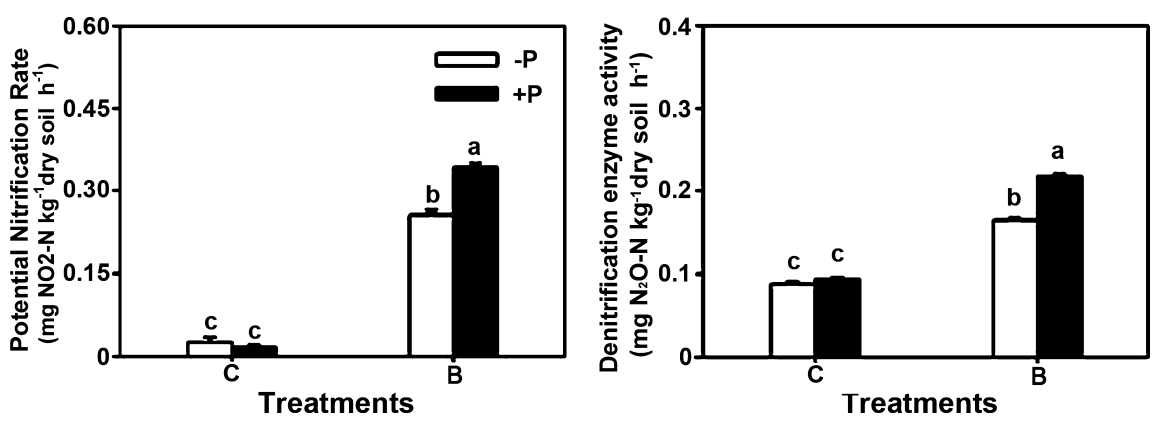

Figure 2. Potential nitrification rates and denitrification enzyme activities in the greenhouse soil under different treatments. Significant differences are indicated by different letters $(p<0.05)$. C: without biochar amendment; B: with biochar amendment; $-\mathrm{P}$ : without rape planting; $+\mathrm{P}$ : with rape planting. 
Table 2. Relative Abundances of Abundant Families in Four Treatments ${ }^{a, b}$

\begin{tabular}{|c|c|c|c|c|}
\hline Families & $\mathrm{C}$ & $\mathrm{CP}$ & B & $\mathrm{BP}$ \\
\hline Acidobacteriaceae & $1.95 \pm 0.13 b$ & $2.22 \pm 0.30 \mathrm{a}$ & $0.36 \pm 0.03 c$ & $0.27 \pm 0.03 c$ \\
\hline Koribacteraceae & $6.31 \pm 0.50 \mathrm{a}$ & $5.47 \pm 2.02 \mathrm{a}$ & $2.61 \pm 0.94 b$ & $1.73 \pm 0.94 b$ \\
\hline Solibacteraceae & $3.29 \pm 0.60 \mathrm{a}$ & $3.40 \pm 1.11 \mathrm{a}$ & $1.07 \pm 0.13 b$ & $1.05 \pm 0.13 b$ \\
\hline Gaiellaceae & $2.07 \pm 0.37 \mathrm{a}$ & $1.90 \pm 0.46 a$ & $1.15 \pm 0.15 b$ & $0.94 \pm 0.15 b$ \\
\hline Bradyrhizobiaceae & $1.29 \pm 0.24 \mathrm{a}$ & $1.84 \pm 0.75 a$ & $0.23 \pm 0.07 b$ & $0.29 \pm 0.07 b$ \\
\hline Rhodospirillaceae & $2.08 \pm 0.12 \mathrm{a}$ & $1.89 \pm 0.28 \mathrm{a}$ & $1.20 \pm 0.22 b$ & $1.37 \pm 0.22 b$ \\
\hline Xanthomonadaceae & $7.74 \pm 1.57 \mathrm{a}$ & $7.25 \pm 1.47 a$ & $3.66 \pm 0.90 b$ & $6.11 \pm 0.90 \mathrm{a}$ \\
\hline Flammeovirgaceae & $0.01 \pm 0.00 c$ & $0.01 \pm 0.00 c$ & $2.49 \pm 0.60 b$ & $3.09 \pm 0.60 \mathrm{a}$ \\
\hline Chitinophagaceae & $0.41 \pm 0.10 b$ & $0.77 \pm 0.27 b$ & $4.76 \pm 1.30 \mathrm{a}$ & $4.83 \pm 1.30 a$ \\
\hline Sphingomonadaceae & $1.71 \pm 0.21 b$ & $1.64 \pm 0.20 b$ & $2.44 \pm 0.29 a$ & $2.74 \pm 0.29 a$ \\
\hline Hyphomicrobiaceae & $1.54 \pm 0.15 c$ & $1.82 \pm 0.28 b$ & $1.83 \pm 0.20 b$ & $2.05 \pm 0.20 \mathrm{a}$ \\
\hline Bacillaceae & $4.99 \pm 1.66 \mathrm{~b}$ & $5.27 \pm 1.27 \mathrm{~b}$ & $8.44 \pm 1.04 \mathrm{a}$ & $4.93 \pm 1.04 b$ \\
\hline Clostridiaceae & $2.60 \pm 0.46 a$ & $2.75 \pm 0.28 \mathrm{a}$ & $2.80 \pm 0.48 a$ & $2.67 \pm 0.48 a$ \\
\hline
\end{tabular}

${ }^{a}$ Different letters in a single column indicate significant difference between the treatments at $p<0.05 .{ }^{b} \mathrm{C}$ : biochar untreated soil without rape, $\mathrm{CP}$ : biochar untreated soil with rape, B: biochar treated soil without rape, and BP: biochar treated soil with rape.

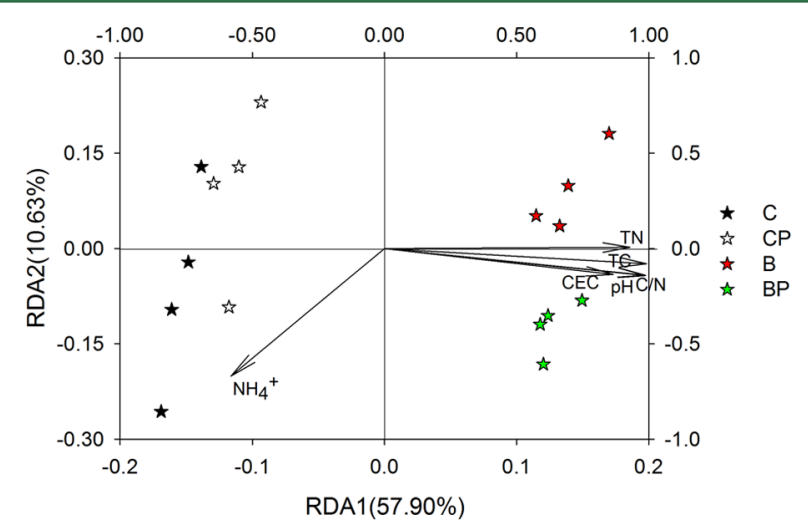

Figure 3. Redundancy analysis (RDA) of soil samples based on bacterial community composition obtained using the family abundances metrix in each sample. C: biochar untreated soil without rape, CP: biochar untreated soil with rape, B: biochar treated soil without rape, BP: biochar treated soil with rape.

explain $57.90 \%$ of the total soil microbial community variation. $\mathrm{TC}, \mathrm{pH}, \mathrm{TN}, \mathrm{C} / \mathrm{N}$ ratio, $\mathrm{CEC}$, and ammonium, moisture, and nitrate were used in the environmental factor matrix to calculate their contribution to the soil microbial community variation among the four treatments. After filtering using the envfit function (999 permutations) with $\mathrm{R}, \mathrm{pH}, \mathrm{TC}, \mathrm{TN}, \mathrm{C} / \mathrm{N}$ ratio, CEC, and ammonium were chosen in the bioplot of $\mathrm{RDA}$. In total, these factors could explain $78.7 \%$ of the soil microbial community composition variation. TC, $\mathrm{pH}, \mathrm{TN}, \mathrm{C} / \mathrm{N}$ ratio, and CEC explained $73.4 \%$ of the soil microbial community composition variation, but the greatest part of the explanation may be their coeffect due to their significant correlation ( $p \leq$ 0.01 ) with each other (SI Table S5).

Transcript Abundances of $16 \mathrm{~S}$ rRNA and Functional Marker Genes. The gene copy numbers in cDNA produced from the reverse transcription of RNA were used to demonstrate the active expressions of total archaea, total bacteria, ammonia-oxidizing archaea, ammonia-oxidizing bacteria and denitrifiers (Figure 4). There were no significant differences among all the four treatments in the transcription of archaeal 16S $r R N A$ and bacterial 16S $r R N A$. Similarly, bacterial amoA, nirS, and nirK gene transcripts showed no responses to biochar either. Among all the genes, only archaea $a m o A$ and nos $Z$ gene transcripts were significantly stimulated by biochar addition. Transcriptions of archaeal amoA increased from 2.04
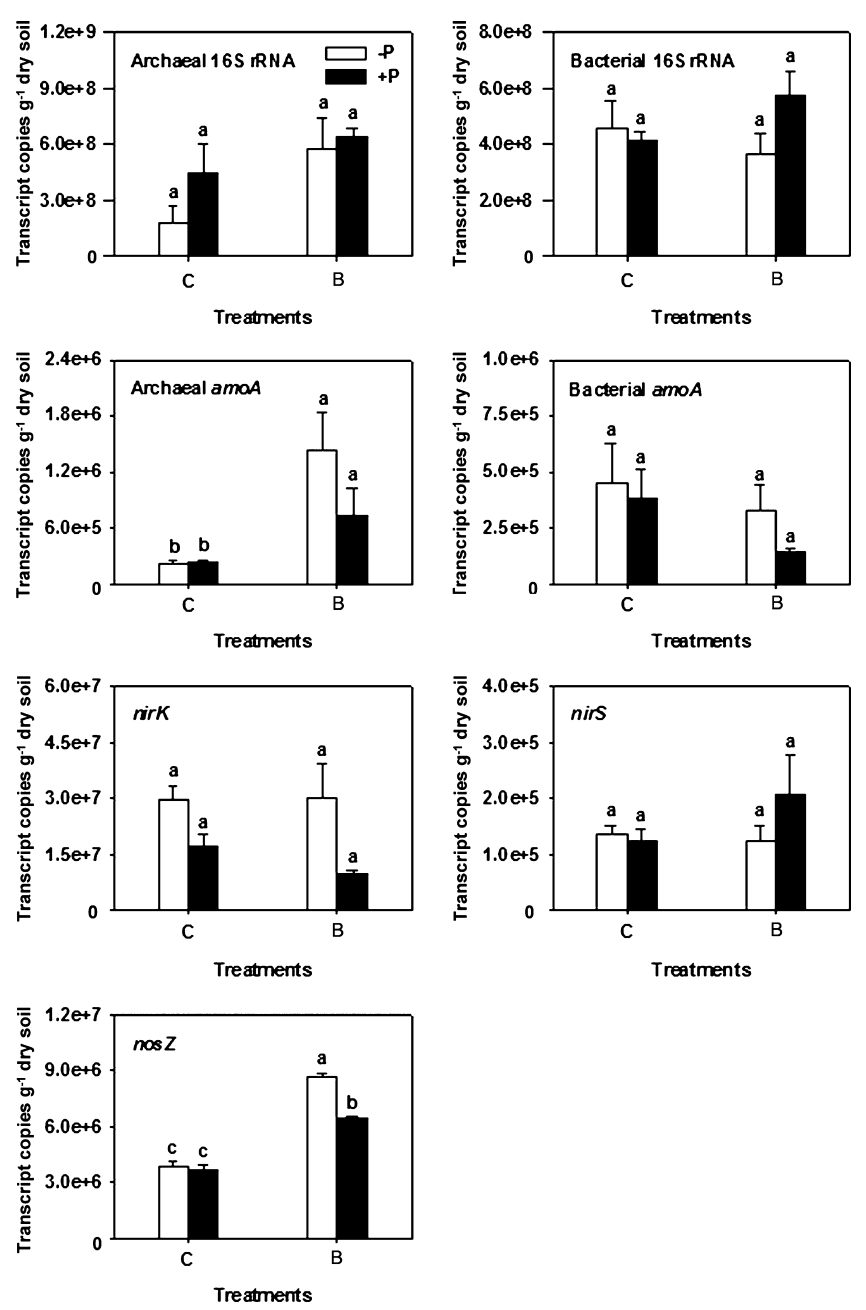

Figure 4. Transcript copy numbers of archaeal and bacterial $16 \mathrm{~S}$ $r R N A$, archaeal and bacterial amoA, nirK, nirS, and nosZ genes in the greenhouse soil under different treatments. Significant differences are indicated by different letters $(p<0.05)$. C: without biochar amendment; B: with biochar amendment; $-\mathrm{P}$ : without rape planting; $+\mathrm{P}$ : with rape planting.

$\times 10^{5}$ to $1.43 \times 10^{6}$ and $2.16 \times 10^{5}$ to $7.29 \times 10^{5}$ transcript copies per $g$ dry soil with and without rape planting, respectively. Transcriptions of nos $Z$ increased from $3.86 \times$ 
$10^{6}$ to $8.59 \times 10^{6}$ and $3.70 \times 10^{6}$ to $6.38 \times 10^{6}$ transcript copies per $g$ dry soil with and without rape planting, respectively. Planting rape slightly inhibited transcriptions of nos $Z$ where biochar was added.

\section{DISCUSSION}

Nitrification, Denitrification and $\mathrm{N}_{2} \mathrm{O}$ Emissions. Nitrification is thought to be an important pathway of soil $\mathrm{N}_{2} \mathrm{O}$ production. However, in this study, the increased nitrification rates by biochar did not result in higher $\mathrm{N}_{2} \mathrm{O}$ emissions. As nitrification is an acidifying process, ${ }^{42}$ alkaline biochar may create much more favorable conditions for nitrifiers thus increasing nitrification rates due to its liming effect. ${ }^{43,44}$ The decreased $\mathrm{N}_{2} \mathrm{O}$ emission and increased nitrification rates demonstrate that the relative contribution of nitrification to $\mathrm{N}_{2} \mathrm{O}$ emissions is much less than that of denitrification (including nitrifier denitrification) in this soil. This result shows that biochar inhibition on nitrification is unlikely to be the mechanism of $\mathrm{N}_{2} \mathrm{O}$ reduction in the soil.

Although the acetylene inhibition method has limitations, these limitations have been shown under longer incubation $(168 \mathrm{~h})$ rather than in short time incubation systems. ${ }^{45}$ In contrast to the hypotheses that biochar may inhibit denitrification by increasing soil aeration or adsorption of $\mathrm{NO}_{3}{ }^{-}$, denitrification enzyme activity in this study was stimulated by biochar. Soil $\mathrm{pH}$ may be the main factor that induces the enhancement of denitrification, as $\mathrm{pH}$ was increased about 2 units by biochar. It is generally agreed that the rate of denitrification (production of $\mathrm{N}_{2} \mathrm{O}+\mathrm{N}_{2}$ ) is optimal in the range of $\mathrm{pH} 7.0-8.0$ while increasing the $\mathrm{pH}$ of acidic soil will accelerate denitrification. ${ }^{46}$ Biochars may increase the activity of $\mathrm{N}_{2} \mathrm{O}$-reductase enzymes of denitrifiers through increasing soil $\mathrm{pH}$, thereby enhancing $\mathrm{N}_{2}$ formation from $\mathrm{N}_{2} \mathrm{O}$ while stimulating denitrification. ${ }^{47}$ Therefore, hypothesis (iii) is the mechanism resulting in decreasing $\mathrm{N}_{2} \mathrm{O}$ emission here: biochar suppresses $\mathrm{N}_{2} \mathrm{O}$ emissions by means of further reducing it to $\mathrm{N}_{2}$. Nevertheless, this conclusion should not be applied to all conditions since the effect of biochar on $\mathrm{N}_{2} \mathrm{O}$ emissions may depend on soil properties and biochar characteristics.

Changes of Soil Chemical Properties and Microbial Community Caused by Biochar. Biochar addition changed soil chemical properties, including increasing soil $\mathrm{pH}, \mathrm{TN}, \mathrm{TC}$, $\mathrm{C} / \mathrm{N}$ ratio, and $\mathrm{CEC}$, and shifted the bacterial community composition. As biochar has been considered unlikely to be used by soil microbes before initial-oils or condensates are decomposed, ${ }^{21}$ and it can not directly influence soil microbial community, the major contribution of chemical properties to the soil microbial community variation and significant correlation between the changed relative phylum abundances and soil chemical properties (SI Table S6) indicates that biochar may affect soil microbial community via improving soil chemical properties. In many previous studies, $\mathrm{pH}$ has always proven to be a prime variable in shaping the soil bacterial community, but mostly from biogeographical perspectives. ${ }^{48,49}$ In this study, soil $\mathrm{pH}$, variation induced by biochar amendment, was also observed to be an important factor in shifting the soil microbial community, contributing $56.5 \%$ of the total variation. Högberg et al. ${ }^{50}$ have reported that the $\mathrm{C} / \mathrm{N}$ ratio was as good as $\mathrm{pH}$ in predicting the soil microbial community. However, in this study the $\mathrm{C} / \mathrm{N}$ ratio was increased somewhat artificially by the addition of $\mathrm{C}$ in the biochar, which was unavailable to microbes in a short incubation period, unlike the natural system investigated by Högberg et al. ${ }^{50}$ Thus, in envfit test, $\mathrm{C} / \mathrm{N}$ ratio was found to be significant in shaping the soil microbial community composition, which could be due to its high correlation with soil $\mathrm{pH}$. Rape planting also showed some influence on the soil microbial community composition but only in treatments with biochar. This result demonstrates that plantation contributes less than chemical properties caused by biochar to the soil microbial community variation; though this should not be generalized as plant root systems vary greatly between species.

Neither total archaeal 16S $r R N A$ nor bacterial 16S $r R N A$ transcription was changed by biochar. Similar results for bacterial abundance at the DNA level were observed in an incubation experiment with biochar amendment under anoxic conditions. ${ }^{26}$ These results demonstrate that biochar may not change microbial size, but shift the microbial community composition by increasing soil microbial $\alpha$-diversity and modifying taxa relative abundances (SI Figures S1 and S4).

At the family level, the relative abundances of Flammeovirgaceae, Chitinophagaceae, Sphingomonadaceae, and Hyphomicrobiaceae were increased by biochar. Flammeovirgaceae and Chitinophagaceae belong to the same order Sphingobacteriales. They play an important role in organic matter decomposition and carbon cycling. ${ }^{51}$ Sphingomonas and Novosphingobium of Sphingomonadaceae have been reported to be able to degrade refractory pollutants ${ }^{52}$ and aromatic-compound, ${ }^{53}$ respectively. Of Hyphomicrobiaceae, a species of Devosia has been shown to modulate and fix nitrogen symbiotically with plants, ${ }^{54}$ and Hyphomicrobium is a genus capable of methyl- trophic denitrification. ${ }^{55}$ These results showed that biochar amendment changed the relative abundances of microbes that underpin carbon and nitrogen cycling in this soil.

Here we also observed an increase in rape shoot biomass after biochar addition. This can be attributed to the shift in soil microbial community composition by biochar, which may drive nutrient (e.g., C, N, and P) cycling thus increasing nutrient availability to crops. Biochar addition has been shown to increase nutrient availability. ${ }^{56}$ These results are of practical economic value when biochar is used for acidic soil amelioration.

Expression of $\mathbf{N}_{2} \mathrm{O}$-Related Functional Genes. The changes in nitrification and denitrification could be due to the fact that biochar amendments change the microbial diversity and taxa relative abundances as biochar did not change total expression of archaeal and bacterial. Biochar increased the activity of nitrifiers and denitrifiers. Archaea may contribute more than bacteria to the enhanced nitrification by biochar, as the expression of archaeal amoA abundances were considerably increased by biochar, but not bacterial amoA (Figure 4). In previous studies, at DNA level, biochar has been shown to increase both archaeal amo $A$ and bacterial amoA compared to control at the last wet cycle of an incubation. ${ }^{27}$ Correspondingly, Ducey et al. ${ }^{25}$ observed a higher bacterial amoA abundance in the presence of biochar at the end of an incubation of 6 months. In this experiment, no fertilizer was added, and ammonium is likely derived from the mineralization of organic matter, to which AOA is more adapted, ${ }^{57,58}$ resulting in no effect on bacterial amoA transcription by biochar.

Although the denitrification process was stimulated by biochar, nirS and nirK transcripts did not change significantly. This may be because nitrite reductase encoded by nirS or nirK was not the limiting factor of denitrification in this study. There is also a possibility that some quantification of bacterial 
functional genes could not represent all denitrifiers, as denitrification can be performed by bacteria, archaea, and fungi. ${ }^{59,60}$ The enhanced expression of nos $Z$ supports the inference that biochar mitigates $\mathrm{N}_{2} \mathrm{O}$ emissions by further reducing it to $\mathrm{N}_{2}$. In their incubation experiment using watersaturated soil microcosms, Harter et al. ${ }^{26}$ also observed that biochar increased the transcript copy numbers of nos $Z$ genes, while having no significant effect on the abundances of nirK and nirS genes. Similar results of incubation experiments have been reported, at DNA level, nos $Z$ gene abundance was significantly higher in the presence of biochar. ${ }^{25,27}$ Thus, our findings suggest that enhanced nos $Z$ gene transcripts by biochar may be the main reason for $\mathrm{N}_{2} \mathrm{O}$ emission reduction regardless of the experimental conditions. Although the soil was only sampled at the end of the incubation and the results of the soil functional genes are limited in explaining $\mathrm{N}_{2} \mathrm{O}$ emissions during the entire incubation, they could explain the lower cumulative $\mathrm{N}_{2} \mathrm{O}$ emission in $\mathrm{B}$ than in $\mathrm{C}$. Because rape may have a more important effect on soil $\mathrm{N}_{2} \mathrm{O}$ emission, biochar did not have a significant effect on the 6th week when the soil was collected, but also result in much lower cumulative $\mathrm{N}_{2} \mathrm{O}$ emission with rape.

In summary, when used in acidified soil amelioration, biochar can increase crop yield through improving soil chemical conditions and changing the availability of nutrients. It can also impact soil microbial community (increasing $\alpha$-diversity of soil microbes and changing relative abundances of taxa) via changing soil chemical properties, thus influencing soil nutrient (e.g., C, N) cycling and controlling greenhouse gas emissions. By contrast, biochar can also enhance soil $\mathrm{N}$ losses to the atmosphere by stimulating both nitrification and denitrification, thus decreasing the efficiency of $\mathrm{N}$-fertilizer utilization. Therefore, the effect of biochar on the use efficiency of $\mathrm{N}$ fertilizer should be considered when it is widely recommended for soil amendments.

\section{ASSOCIATED CONTENT}

\section{S Supporting Information}

Basic properties of the soil and biochar used in biochar amendment pot trial study in greenhouse (Table S1), elemental composition of the soil and biochar used in biochar amendment pot trial study in greenhouse (Table S2), primers and PCR conditions used for the real-time PCR in biochar amendment pot trial study (Table S3), comparison of $\alpha$-diversity indices in four treatments with or without biochar amendment (Table S4), correlations of soil properties (Table S5), correlations of abundant phyla with soil properties (Table S6), $\mathrm{N}_{2} \mathrm{O}$ accumulation during determination period; the accumulation of $\mathrm{N}_{2} \mathrm{O}$ is calculated by adding $\mathrm{N}_{2} \mathrm{O}$ emission in $2 \mathrm{~h}$ determined each week; the letters were used to show the differences among treatments (Figure S1), rarefaction of observed species at a sequencing depth of 19772 sequences per sample (Figure S2), relative abundances of bacterial community composition at phylum level detected in biochar treated and untreated soils (Figure S3), relative abundances of taxa at class level in the eight dominant phyla detected in biochar treated and untreated soils (I: Proteobacteria, II: Firmicutes, III: Acidobacteria, IV: Actinobacteria, V: Chloroflexi, VI: Gemmatimonadetes, VII: Bacteroidetes, VIII: TM7); the abundance is presented in terms of an average percentage of four replicates, classified by RDP Classifier at a confidence threshold of 97\%; "Other" refers to the sum of unclassified sequences and all other taxa unnamed. C: biochar untreated soil without rape, CP: biochar untreated soil with rape, B: biochar treated soil without rape, BP: biochar treated soil with rape; the letters were used to show the differences among treatments at phylum level (Figure S4), redundancy analysis (RDA) of bacterial community composition obtained using the family abundances metrix in each sample; and the symbols represent different taxa at the family level (Figure S5). This material is available free of charge via the Internet at http://pubs.acs.org.

\section{AUTHOR INFORMATION}

\section{Corresponding Author}

*Phone: (+86) 592 6190977; fax: (+86) 592 6190977; e-mail: ygzhu@iue.ac.cn.

\section{Author Contributions}

"These authors contributed equally.

Notes

The authors declare no competing financial interest.

\section{ACKNOWLEDGMENTS}

This work was supported by the International Science \& Technology Cooperation Program of China (2011 DFB91710) and National Natural Science Foundation of China (41271324). We thank Lars Molstad from the Norwegian UMB-Nitrogen-group (http://www.umb.no/nitrogengroup/) for designing and programming of our robotized (incubation) system for analyzing gas kinetics. We thank Professor Stephen Chapman from The James Hutton Institute for carefully revising earlier versions of this manuscript. We thank Valerie Gail Gibson from Institute of Urban Environment for proofreading the manuscript.

\section{REFERENCES}

(1) Guo, J. H.; Liu, X. J.; Zhang, Y.; Shen, J. L.; Han, W. X.; Zhang, W. F.; Christie, P.; Goulding, K. W. T.; Vitousek, P. M.; Zhang, F. S. Significant acidification in major Chinese croplands. Science 2010, 327 (5968), 1008-1010.

(2) Zhou, J.; Xia, F.; Liu, X.; He, Y.; Xu, J.; Brookes, P. C. Effects of nitrogen fertilizer on the acidification of two typical acid soils in South China. J. Soils Sediments 2014, 14 (2), 415-422.

(3) Meng, L.; Ding, W. X.; Cai, Z. C. Long-term application of organic manure and nitrogen fertilizer on $\mathrm{N}_{2} \mathrm{O}$ emissions, soil quality and crop production in a sandy loam soil. Soil Biol. Biochem. 2005, 37 (11), 2037-2045.

(4) Pietri, J. C. A.; Brookes, P. C. Relationships between soil $\mathrm{pH}$ and microbial properties in a UK arable soil. Soil Biol. Biochem. 2008, 40 (7), 1856-1861.

(5) Raut, N.; Dorsch, P.; Sitaula, B. K.; Bakken, L. R. Soil acidification by intensified crop production in South Asia results in higher $\mathrm{N}_{2} \mathrm{O}$ / $\left(\mathrm{N}_{2}+\mathrm{N}_{2} \mathrm{O}\right)$ product ratios of denitrification. Soil Biol. Biochem. 2012, $55,104-112$.

(6) Qu, Z.; Wang, J.; Almoy, T.; Bakken, L. R. Excessive use of nitrogen in Chinese agriculture results in high $\mathrm{N}_{2} \mathrm{O} /\left(\mathrm{N}_{2} \mathrm{O}+\mathrm{N}_{2}\right)$ product ratio of denitrification, primarily due to acidification of the soils. Glob. Change Biol. 2014, 20 (5), 1685-98.

(7) Yuan, J. H.; Xu, R. K. The amelioration effects of low temperature biochar generated from nine crop residues on an acidic Ultisol. Soil Use Manage. 2011, 27 (1), 110-115.

(8) Novak, J. M.; Cantrell, K. B.; Watts, D. W.; Busscher, W. J.; Johnson, M. G. Designing relevant biochars as soil amendments using lignocellulosic-based and manure-based feedstocks. J. Soils Sediments 2014, 14 (2), 330-343.

(9) Khan, S.; Chao, C.; Waqas, M.; Arp, H. P. H.; Zhu, Y. G. Sewage sludge biochar influence upon rice (Oryza sativa L) yield, metal bioaccumulation and greenhouse gas emissions from acidic paddy soil. Environ. Sci. Technol. 2013, 47 (15), 8624-8632. 
(10) Rees, F.; Simonnot, M. O.; Morel, J. L. Short-term effects of biochar on soil heavy metal mobility are controlled by intra-particle diffusion and soil pH increase. Eur. J. Soil Sci. 2014, 65 (1), 149-161.

(11) Cayuela, M. L.; Sanchez-Monedero, M. A.; Asuncion, R.; Kelly, H.; Akio, E.; Johannes, L. Biochar and denitrification in soils: When, how much and why does biochar reduce $\mathrm{N}_{2} \mathrm{O}$ emissions? Sci. Rep. 2013, 3, 1732.

(12) Nelissen, V.; Saha, B. K.; Ruysschaert, G.; Boeckx, P. Effect of different biochar and fertilizer types on $\mathrm{N}_{2} \mathrm{O}$ and $\mathrm{NO}$ emissions. Soil Biol. Biochem. 2014, 70, 244-255.

(13) Cheng, Y.; Cai, Z. C.; Chang, S. X.; Wang, J.; Zhang, J. B. Wheat straw and its biochar have contrasting effects on inorganic $\mathrm{N}$ retention and $\mathrm{N}_{2} \mathrm{O}$ production in a cultivated Black Chernozem. Biol. Fertil. Soils 2012, 48 (8), 941-946.

(14) Clough, T. J.; Bertram, J. E.; Ray, J. L.; Condron, L. M.; O'Callaghan, M.; Sherlock, R. R.; Wells, N. S. Unweathered wood biochar impact on nitrous oxide emissions from a bovine-urineamended pasture soil. Soil Sci. Soc. Am. J. 2010, 74 (3), 852-860.

(15) Braker, G.; Conrad, R. Diversity, structure, and size of $\mathrm{N}_{2} \mathrm{O}$ producing microbial communities in soils- what matters for their functioning? Adv. Appl. Microbiol. 2011, 75, 33-70.

(16) Lan, T.; Han, Y.; Roelcke, M.; Nieder, R.; Cai, Z. Effects of the nitrification inhibitor Dicyandiamide (DCD) on gross $\mathrm{N}$ transformation rates and mitigating $\mathrm{N}_{2} \mathrm{O}$ emission in paddy soils. Soil Biol. Biochem. 2013, 67, 174-182.

(17) Yanai, Y.; Toyota, K.; Okazaki, M. Effects of charcoal addition on $\mathrm{N}_{2} \mathrm{O}$ emissions from soil resulting from rewetting air-dried soil in short-term laboratory experiments. Soil Sci. Plant Nutr. 2007, 53 (2), 181-188.

(18) Van Zwieten, L.; Kimber, S.; Morris, S.; Downie, A.; Berger, E.; Rust, J.; Scheer, C. Influence of biochars on flux of $\mathrm{N}_{2} \mathrm{O}$ and $\mathrm{CO}_{2}$ from Ferrosol. Aust. J. Soil Res. 2010, 48 (6-7), 555-568.

(19) Cornelissen, G.; Rutherford, D. W.; Arp, H. P. H.; Dorsch, P.; Kelly, C. N.; Rostad, C. E. Sorption of pure $\mathrm{N}_{2} \mathrm{O}$ to biochars and other organic and inorganic materials under anhydrous conditions. Environ. Sci. Technol. 2013, 47 (14), 7704-7712.

(20) Spokas, K. A.; Baker, J. M.; Reicosky, D. C. Ethylene: Potential key for biochar amendment impacts. Plant Soil 2010, 333 (1-2), 443452.

(21) Thies, J. E.; Rillig, M. C. Characteristics of Biochar: Biological Properties. In Biochar for Environmental Management: Science and Technology; Lehmann \& Joseph, Eds.; Earthscan: London, 2009; pp 85-105.

(22) Smith, J. L.; Collins, H. P.; Bailey, V. L. The effect of young biochar on soil respiration. Soil Biol. Biochem. 2010, 42 (12), 23452347.

(23) Zimmerman, A. R. Abiotic and microbial oxidation of laboratory-produced black carbon (biochar). Environ. Sci. Technol. 2010, 44 (4), 1295-1301.

(24) Anderson, C. R.; Condron, L. M.; Clough, T. J.; Fiers, M.; Stewart, A.; Hill, R. A.; Sherlock, R. R. Biochar induced soil microbial community change: Implications for biogeochemical cycling of carbon, nitrogen and phosphorus. Pedobiologia 2011, 54 (5-6), 309-320.

(25) Ducey, T. F.; Ippolito, J. A.; Cantrell, K. B.; Novak, J. M.; Lentz, R. D. Addition of activated switchgrass biochar to an aridic subsoil increases microbial nitrogen cycling gene abundances. Appl. Soil Ecol. 2013, 65, 65-72.

(26) Harter, J.; Krause, H.-M.; Schuettler, S.; Ruser, R.; Fromme, M.; Scholten, T.; Kappler, A.; Behrens, S. Linking $\mathrm{N}_{2} \mathrm{O}$ emissions from biochar-amended soil to the structure and function of the N-cycling microbial community. ISME J. 2014, 8 (3), 660-674.

(27) Van Zwieten, L.; Singh, B. P.; Kimber, S. W. L.; Murphy, D. V.; Macdonald, L. M.; Rust, J.; Morris, S. An incubation study investigating the mechanisms that impact $\mathrm{N}_{2} \mathrm{O}$ flux from soil following biochar application. Agri., Ecosyst. Environ. 2014, 191 (0), 53-62.

(28) Zhou, H. W.; Li, D. F.; Tam, N. F. Y.; Jiang, X. T.; Zhang, H.; Sheng, H. F.; Qin, J.; Liu, X.; Zou, F. BIPES, a cost-effective highthroughput method for assessing microbial diversity. ISME J. 2011, 5 (4), 741-749.
(29) Braker, G.; Zhou, J. Z.; Wu, L. Y.; Devol, A. H.; Tiedje, J. M. Nitrite reductase genes (nirK and nirS) as functional markers to investigate diversity of denitrifying bacteria in Pacific northwest marine sediment communities. Appl. Environ. Microbiol. 2000, 66 (5), 20962104.

(30) Kloos, K.; Mergel, A.; Rosch, C.; Bothe, H. Denitrification within the genus Azospirillum and other associative bacteria. Aust. J. Plant Physiol. 2001, 28 (9), 991-998.

(31) Francis, C. A.; Roberts, K. J.; Beman, J. M.; Santoro, A. E.; Oakley, B. B. Ubiquity and diversity of ammonia-oxidizing archaea in water columns and sediments of the ocean. Proc. Natl. Acad. Sci. U.S.A. 2005, 102 (41), 14683-14688.

(32) Molstad, L.; Dorsch, P.; Bakken, L. R. Robotized incubation system for monitoring gases $\left(\mathrm{O}_{2}, \mathrm{NO}, \mathrm{N}_{2} \mathrm{O}, \mathrm{N}_{2}\right)$ in denitrifying cultures. J. Microbiol. Methods 2007, 71 (3), 202-211.

(33) He, J. Z.; Shen, J. P.; Zhang, L. M.; Zhu, Y. G.; Zheng, Y. M.; $\mathrm{Xu}, \mathrm{M}$. G.; Di, H. Quantitative analyses of the abundance and composition of ammonia-oxidizing bacteria and ammonia-oxidizing archaea of a Chinese upland red soil under long-term fertilization practices. Environ. Microbiol. 2007, 9 (9), 2364-2374.

(34) Guo, G. X.; Deng, H.; Qiao, M.; Mu, Y. J.; Zhu, Y. G. Effect of pyrene on denitrification activity and abundance and composition of denitrifying community in an agricultural soil. Environ. Pollut. 2011, 159 (7), 1886-1895.

(35) Huse, S. M.; Dethlefsen, L.; Huber, J. A.; Welch, D. M.; Relman, D. A.; Sogin, M. L. Exploring microbial diversity and taxonomy using SSU rRNA hypervariable tag sequencing. PloS Genet. 2008, 4, e1000255.

(36) Hamady, M.; Walker, J. J.; Harris, J. K.; Gold, N. J.; Knight, R. Error-correcting barcoded primers for pyrosequencing hundreds of samples in multiplex. Nat. Methods 2008, 5 (3), 235-237.

(37) Ahn, S. J.; Costa, J.; Emanuel, J. R. PicoGreen quantitation of DNA: effective evaluation of samples pre- or post-PCR. Nucleic Acids Res. 1996, 24 (13), 2623-2625.

(38) Griffiths, R. I.; Whiteley, A. S.; O’Donnell, A. G.; Bailey, M. J. Rapid method for coextraction of DNA and RNA from natural environments for analysis of ribosomal DNA- and rRNA-based microbial community composition. Appl. Environ. Microbiol. 2000, 66 (12), 5488-5491.

(39) Caporaso, J. G.; Kuczynski, J.; Stombaugh, J.; Bittinger, K.; Bushman, F. D.; Costello, E. K.; Fierer, N.; Pena, A. G.; Goodrich, J. K.; Gordon, J. I.; Huttley, G. A.; Kelley, S. T.; Knights, D.; Koenig, J. E.; Ley, R. E.; Lozupone, C. A.; McDonald, D.; Muegge, B. D.; Pirrung, M.; Reeder, J.; Sevinsky, J. R.; Tumbaugh, P. J.; Walters, W. A.; Widmann, J.; Yatsunenko, T.; Zaneveld, J.; Knight, R. QIIME allows analysis of high-throughput community sequencing data. Nat. Methods 2010, 7 (5), 335-336.

(40) Lozupone, C.; Hamady, M.; Knight, R. UniFrac-An online tool for comparing microbial community diversity in a phylogenetic context. BMC Bioinformatics 2006, 7.

(41) Oksanen, J. Multivariate analysis of ecological communities in R: vegan tutorial. [WWW document]. URL http://cc.oulu.fi/ jarioksa/ opetus/metodi/vegantutor.pdf. 2-8-2013. Ref Type: Internet Communication.

(42) Bolan, N. S.; Hedley, M. J.; White, R. E. Processes of soil acidification during nitrogen cycling with emphasis on legume based pastures. Plant Soil 1991, 134 (1), 53-63.

(43) Prommer, J.; Wanek, W.; Hofhansl, F.; Trojan, D.; Offre, P.; Urich, T.; Schleper, C.; Sassmann, S.; Kitzler, B.; Soja, G.; HoodNowotny, R. C. Biochar decelerates soil organic nitrogen cycling but stimulates soil nitrification in a temperate arable field trial. PloS One 2014, 9, e86388.

(44) Ulyett, J.; Sakrabani, R.; Kibblewhite, M.; Hann, M. Impact of biochar addition on water retention, nitrification and carbon dioxide evolution from two sandy loam soils. Eur. J. Soil Sci. 2014, 65 (1), 96104.

(45) Yeomans, J. C.; Beauchamp, E. G. Limited inhibition of nitrousoxide reduction in soil in presence of acetylene. Soil Biol. Biochem. 1978, 10 (6), 517-519. 
(46) Peterjohn, W. T. Denitrification-enzyme content and activity in desert soils. Soil Biol. Biochem. 1991, 23 (9), 845-855.

(47) Simek, M.; Cooper, J. E. The influence of soil $\mathrm{pH}$ on denitrification: Progress towards the understanding of this interaction over the last 50 years. Eur. J. Soil Sci. 2002, 53 (3), 345-354.

(48) Shen, C.; Xiong, J.; Zhang, H.; Feng, Y.; Lin, X.; Li, X.; Liang, W.; Chu, H. Soil $\mathrm{pH}$ drives the spatial distribution of bacterial communities along elevation on Changbai Mountain. Soil Biol. Biochem. 2013, 57 (2), 204-211.

(49) Fierer, N.; Jackson, R. B. The diversity and biogeography of soil bacterial communities. Proc. Natl. Acad. Sci. U.S.A. 2006, 103 (3), 626-631.

(50) Högberg, M. N.; Högberg, P.; Myrold, D. D. Is microbial community composition in boreal forest soils determined by $\mathrm{pH}$, C-to$\mathrm{N}$ ratio, the trees, or all three? Oecologia 2007, 150 (4), 590-601.

(51) Yoon, J.; Ishikawa, S.; Kasai, H.; Yokota, A. Perexilibacter aurantiacus gen. nov., sp nov., a novel member of the family 'Flammeovirgaceae' isolated from sediment. Int. J. Syst. Evol. Microbiol. 2007, 57, 964-968.

(52) White, D. C.; Sutton, S. D.; Ringelberg, D. B. The genus Sphingomonas: Physiology and ecology. Curr. Opin. Biotechnol. 1996, 7 (3), 301-306.

(53) Liu, Z. P.; Wang, B. J.; Liu, Y. H.; Liu, S. J. Novosphingobium taihuense sp. nov., a novel aromatic-compound-degrading bacterium isolated from Taihu Lake, China. Int. J. Syst. Evol. Microbiol. 2005, 55, 1229-1232.

(54) Rivas, R.; Velazquez, E.; Willems, A.; Vizcaino, N.; Subba-Rao, N. S.; Mateos, P. F.; Gillis, M.; Dazzo, F. B.; Martinez-Molina, E. A new species of Devosia that forms a unique nitrogen-fixing root-nodule symbiosis with the aquatic legume Neptunia natans (L.f.) Druce. Appl. Environ. Microbiol. 2002, 68 (11), 5217-5222.

(55) Liessens, J.; Germonpre, R.; Kersters, I.; Beernaert, S.; Verstraete, W. Removing nitrate with a methylotrophic fluidized bed: Microbiological water quality. Am. Water Works Assn. J. 1993, 85 (4), 155-161.

(56) Novak, J. M.; Busscher, W. J.; Laird, D. L.; Ahmedna, M.; Watts, D. W.; Niandou, M. A. S. Impact of biochar amendment on fertility of a southeastern coastal plain soil. Soil Sci. 2009, 174 (2), 105-112.

(57) Verhamme, D. T.; Prosser, J. I.; Nicol, G. W. Ammonia concentration determines differential growth of ammonia-oxidising archaea and bacteria in soil microcosms. ISME J. 2011, 5 (6), 10671071.

(58) Levicnik-Hoefferle, S.; Nicol, G. W.; Ausec, L.; Mandic-Mulec, I.; Prosser, J. I. Stimulation of thaumarchaeal ammonia oxidation by ammonia derived from organic nitrogen but not added inorganic nitrogen. FEMS Microbiol. Ecol. 2012, 80 (1), 114-123.

(59) Shoun, H.; Kim, D. H.; Uchiyama, H.; Sugiyama, J. Denitrification by fungi. FEMS Microbiol. Lett. 1992, 94 (3), 277-281.

(60) Philippot, L. Denitrifying genes in bacterial and Archaeal genomes. Biochim. Biophys.Acta. 2002, 1577 (3), 355-376. 